\title{
KONTAKT Z DZIECKIEM PRZED URODZENIEM
}

\author{
PARENTS - INFANT ATTACHMENT BEFORE CHILDBIRTH
}

\section{Teresa Barbara Slosorz}

Wydział Nauk o Zdrowiu, Wyższa Szkoła Inżynierii i Zdrowia w Warszawie

DOI: https://doi.org/10.20883/ppnoz.2019.24

\section{STRESZCZENIE}

Streszczenie. Przebieg ciąży jest monitorowany badaniem ultrasonograficznym (USG), które umożliwia „ogląd płodu" w łonie matki. Dla rodziców zobrazowanie wyglądu dziecka w tej formie wiąże się z potwierdzeniem ciąży i z poczuciem jego dobrostanu. Oczywisty jest również fakt, że po zaakceptowaniu nowej sytuacji w głowach rodziców pojawią się myśli dotyczące wyglądu ich dziecka. Kłębią się pytania typu: do kogo będzie podobne, jaki będzie miato kolor włosów, oczu itd.

Cel pracy. Uzyskanie odpowiedzi na pytanie: Czy rodzice nawiązują kontakt z dzieckiem w życiu prenatalnym i projektują jego wizualizację?

Materiał i metody. Badania przeprowadzono na terenie województwa wielkopolskiego wśród losowo wybranych 80 osób (40 kobiet i tyle samo mężczyzn) uczestników szkół rodzenia. Kontakt z dzieckiem przed urodzeniem oceniono metodą sondażu diagnostycznego przy użyciu kwestionariusza ankiety własnego autorstwa.

Wyniki. Z przeprowadzonej analizy wynika, że zarówno osoby oczekujące pierwszego dziecka, jak i te, które posiadają już potomstwo, nawiązują kontakt z dzieckiem nienarodzonym i w mniejszym lub większym stopniu projektują jego wygląd; nierzadko utożsamiając podobieństwa do któregoś z członków rodziny.

Wnioski. Badania ankietowe dowodzą, że dla rodziców ważne są kolejne badania USG, ponieważ obraz pojawiający się na monitorze umożliwia wyobrażenie realnej postaci dziecka, co z kolei potwierdza fakt, że wizualizacja nienarodzonego dziecka ma pozytywny wpływ na uczucia i emocje rodziców związane z oczekiwaniem na jego przyjęcie.

Słowa kluczowe: kontakt rodzic-dziecko, więź emocjonalna, ciąża, wizualizacja.

\section{ABSTRACT}

Introduction. The present study shows that ultrasonography is not only a great tool for the infant condition to monitor, but plays a huge role as a confirmation of having child for parents. As soon as they accept new situation, they start to imagine how the child looks like to who's face is similar to, what colour of eyes or hear is having etc. Basically from that moment it starts exceptional attachment between them.

Aim. The aim of the study was to know if parents make a relationship with their child during pregnancy and do they develop picture of her or him?

Material and methods. The research tool was the self-designed interview questionnaire. The study group comprised of 80 randomly chosen participants who are 40 women and 40 men in wielkopolska region attending pregnancy classes.

Conclusions. Obtained results indicate that is no difference between parents expecting their first or next child. They all consider ultrasonography as important for them to create image of new descendant. Very often they are developing emotional bond during pregnancy based on that and looking for similar to them appearance features. In fact that generates positive emotion and welcoming environment for expecting child.

Keywords: attachment, parent-child relationship, emotional bond, pregnancy, visualisation.

\section{Wstęp}

Na przestrzeni dziejów kontakt z dzieckiem przed urodzeniem budził szereg kontrowersji. W dawnych czasach okres ciąży zwany "stanem błogosławionym" zabraniał wręcz nadmiernego interesowania się tym, co dzieje się z ciałem i w ciele kobiety. Przyjmowano ten stan za pewnego rodzaju "niewiadomą", a wszelki kontakt z dzieckiem pozostawiano na czas po narodzinach. Tym bardziej nie sprzyjało to myśleniu w kategoriach nawiązywania kontaktu, poprzez wyobrażanie „kogoś", kto wzrasta w łonie matki.

Krągłości kobiece zawoalowane ubiorem, maskowały nową sytuację często do samego rozwiązania. Jeszcze do niedawna większość kobiet nie wiedziała, kogo (w znaczeniu płci) nosi pod swoim sercem. Powstrzymywało to przyszłe mamy przed identyfikacją z konkretnym dzieckiem w znaczeniu: syn, córka. Tylko dla bardziej 'doświadczonych kobiet' o płci dziecka mógł świadczyć: „kształt brzucha" lub inne detale w stylu, że: „córka odbiera urodę matce" lub że: „w ciąży należy jeść za dwoje”.

Obecnie nie ma chyba kobiety, która po pierwszych badaniach prenatalnych, najdalej do połowy ciąży, nie wiedziałaby, kto wzrasta w jej łonie. Mając wiedzę na temat płci, łatwiej jest lokalizować i wizualizować uczucia oraz emocje związane z potomkiem. 
Z chwilą powstania pierwszych szkół rodzenia doceniona została także rola taty dziecka. Wcześniej głównie był zaangażowany w sprawy formalno-urzędowe. Obecność przy narodzinach (własnego dziecka) wykraczała poza wszelkie normy obyczajowe i była wręcz niemożliwa. A przecież dziecko od chwili poczęcia ma rodziców!

Okres ciąży powoduje nie tylko zmiany w ciele i psychice każdej mamy, ale istotny wpływ mają także prawidłowe relacje z ojcem dziecka i pozostałymi członkami rodziny. Sytuacja emocjonalna ciężarnej jest niezwykle ważna dla niej i dla jej nienarodzonego dziecka. W wielu opracowaniach na podstawie badań stwierdzono, że u kobiet ujawniających negatywne emocje (lęk i smutek) częściej pojawiały się dolegliwości (nudności, wymioty), powikłania ciąży i niepowodzenia położnicze oraz wady rozwojowe u noworodków [1].

Zatem, aby dziecko mogło prawidłowo się rozwijać i czuć bezpiecznie, przyszła mama powinna zachowywać spokój własny i mieć wsparcie od osób z najbliżzzego otoczenia.

W stanie dobrego samopoczucia we krwi kobiety zaczynają krążyć endorfiny - grupa hormonów peptydowych, które pozytywnie wpływają zarówno na organizm jej i dziecka [7].

Pierwszy kontakt z nienarodzonym dzieckiem rodzice mogą nawiązywać jeszcze przed jego pierwszymi ruchami wyczuwalnymi przez matkę [5]. Początkowo mogą to być chwile relaksu spędzone razem w poczuciu jedności obojga rodziców. Z czasem wraz z rozwojem dziecka, kontakt może przybierać coraz bogatsze formy np. rozmowa werbalna "do brzucha" lub porozumiewanie się z dzieckiem w myślach [6]

Rozmowę z dzieckiem można prowadzić w każdych warunkach, wykorzystując wolne chwile w ciągu dnia. O czym rozmawiać? O wszystkim, co nas dotyczy o: wydarzeniach w danej chwili, samopoczuciu, planach dotyczących dziecka [4]. Podobny kontakt z dzieckiem powinien nawiązać także tata.

W szkołach rodzenia stosuje się formę nazywaną niekiedy relaksem połączonym ze "sterowaną" fantazją na temat spotkania z dzieckiem. Jedną z form jest malowanie przez ojca lub osobę towarzysząca na brzuchu matki - wizerunku dziecka [2].

Jednak niezależnie od miejsca i czasu oczekiwania na narodziny dziecka sprawą najważniejszą jest nawiązanie dobrego kontaktu rodziców i członków rodziny z potomkiem.

\section{Cel badań}

Głównym celem pracy było uzyskanie odpowiedzi na pytanie: Czy rodzice nawiązują kontakt z dzieckiem w życiu prenatalnym i projektują jego wizualizację przed urodzeniem? W tym celu postawiono kilka hipotez:

1. Rodzice nawiązujący wczesny kontakt z dzieckiem łatwiej akceptują ciążę.

2. Wizualizacja nienarodzonego dziecka ma pozytywny wpływ na jego przyjęcie.

3. Myśli rodziców o dziecku budzą duże emocje i wpływają na ich uczucia.

Hipotezy poddane weryfikacji za pomocą zebranego materiału badawczego stanowią istotną część pracy.

\section{Materiał i metody}

Do realizacji celu pracy zastosowano metodę sondażu diagnostycznego wykorzystując opracowane narzędzie badawcze w postaci kwestionariusza ankiety, składającego się z 10 pytań (6 zamkniętych i 4 otwartych - opisowych). Pytania w kwestionariuszu sformułowano tak, aby po przeprowadzeniu analizy uzyskać odpowiedź na postawiony problem badawczy. Ankiety w ilości 100 egzemplarzy zostały rozprowadzone wśród losowo wybranych osób na terenie północnej części województwa wielkopolskiego w terminie od 20 maja - 20 czerwca 2018 r. Respondentami byli uczestnicy szkół rodzenia oczekujący narodzin pierwszego dziecka oraz osoby posiadające już dziecko/dzieci. Ostatecznie w badaniu wzięło udział 80 osób w równym podziale liczbowym: 40 kobiet i 40 mężczyzn.

\section{Wyniki badań}

W badanej grupie osób oczekujących na narodziny dziecka 18 (tj. 45\%) kobiet i 26 (tj. 65\%) mężczyzn zadeklarowało, że nie posiada jeszcze potomstwa (Ryciny 1 i 2 ).

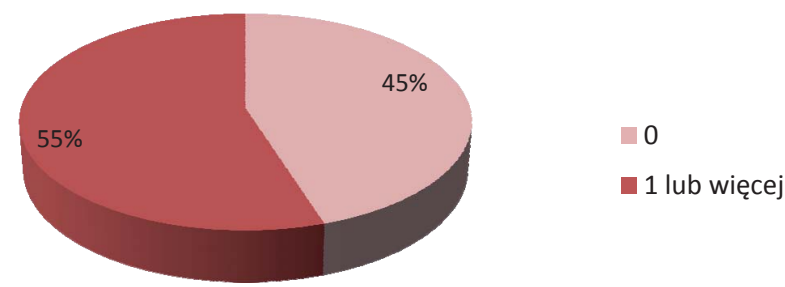

Rycina 1. Ankietowane kobiety - liczba dzieci

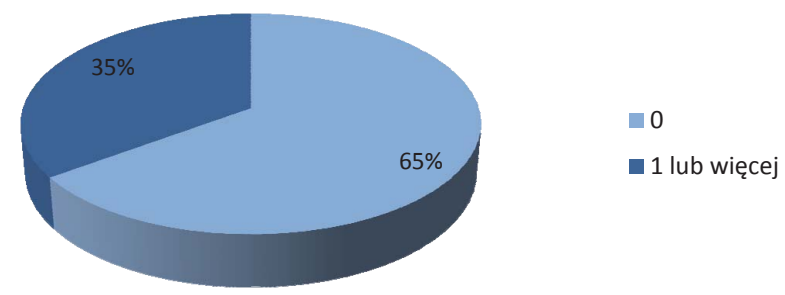

Rycina 2. Ankietowani mężczyźni - liczba dzieci 
Przystępując do analizy udzielonych odpowiedzi w kwestii reakcji na wiadomość o ciąży, stwierdzono, że w przypadku 24 (tj. 60\%) ankietowanych kobiet była pozytywna. U co czwartej respondentki 10 (tj. 25\%) wywołała tzw. „mieszane uczucia”, natomiast dla blisko co siódmej (6 tj.15\%) była zaskoczeniem i wzbudziła negatywne emocje (Rycina 3).
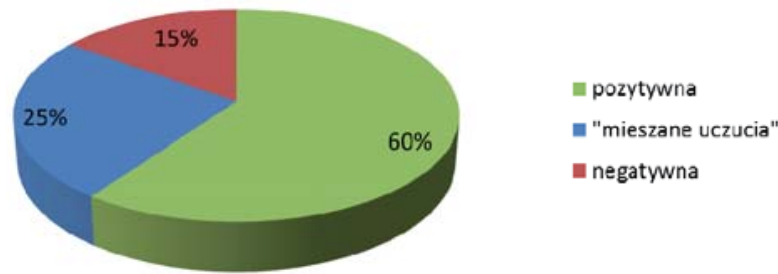

Rycina 3. Reakcja kobiet na wiadomość o ciąży

W przypadku mężczyzn na wieść o ojcostwie pozytywnie zareagowało 30 (tj. 75\%) ankietowanych. Zaledwie dwóch (tj. 5\%) wyraziło negatywne odczucia, a co piąty mężczyzna (8 tj.20\%) określił swoją reakcję $w$ kategorii "mieszane uczucia” (Rycina 4).
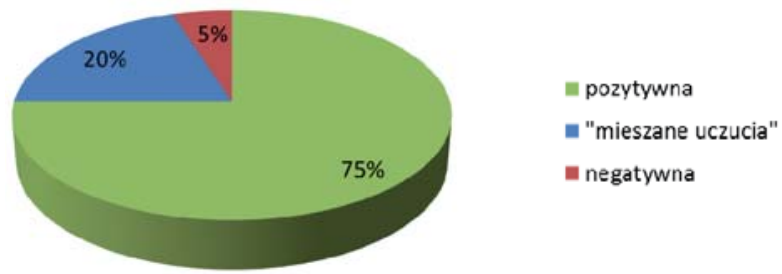

Rycina 4. Reakcja mężczyzn na wiadomość o ciąży

W kolejnym pytaniu poproszono o wskazanie sposobu nawiązania kontaktu z dzieckiem. Porównując odpowiedzi kobiet i mężczyzn, stwierdzono wyraźną różnicę. Ojcowie chętniej nawiązywali kontakt z nienarodzonym dzieckiem po wykonaniu USG lub z chwilą, gdy brzuch kobiety zaczął nabierać okrągłego kształtu - najpóźniej do połowy czasu trwania ciąży. Kobiety natomiast znacznie wcześniej, nierzadko tuż po potwierdzeniu ciąży testem ciążowym, najpóźniej do czasu wystąpienia pierwszych ruchów płodu.

Z racji możliwości udzielenia więcej niż jednej odpowiedzi (Rycina 5) ankietowani mogli wskazać kilka sposobów nawiązywania kontaktu z dzieckiem przed urodzeniem. Najczęściej powtarzającą się formą kontaktu było mówienie. Odpowiedzi takiej udzieliło 35 (tj. 87,5\%) mężczyzn i 27 (tj. 67,5?\%) kobiet oraz dotyk - tu wynik był zblizony 31 (tj. 77,5\%) kobiet i 29 (tj. 72,5\%) mężczyzn. Żaden z badanych mężczyzn nie próbował nawiązać kontaktu z dzieckiem poprzez słuchanie muzyki i przekazywanie myśli. Tutaj przewagą wykazały się kobiety - co ósma potwierdziła słuchanie muzyki (5 tj.12,5\%), a co trzecia (13 tj. 32,5\%) projektowanie myśli pod adresem dziecka.

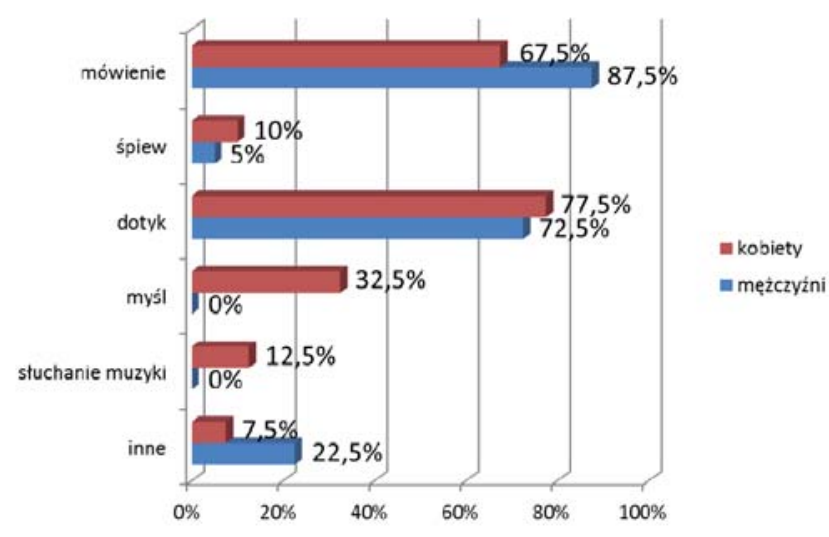

Rycina 5. Sposoby nawiązywania kontaktu z dzieckiem

W następnym pytaniu poproszono ankietowane osoby o wyrażenie wyobrażeń na temat nienarodzonego dziecka. Prawie co siódmy mężczyzna (6 tj.15\%) i tylko dwie kobiety (2 tj. 5\%) deklarowali, że w ogóle nie wyobrażają sobie życia prenatalnego ich dziecka. Podobnie dla 5\% zarówno kobiet i mężczyzn wygląd dziecka nie miał znaczenia Częściej natomiast zastanawiali się nad podobieństwem do członków rodziny (rodziców, dziadków z obu stron) i jak wynika z badań miało to nieco większe znaczenie dla kobiet (13 tj. 32,5\%) niż dla mężczyzn (9 tj. 22,5\%) (Rycina 6).

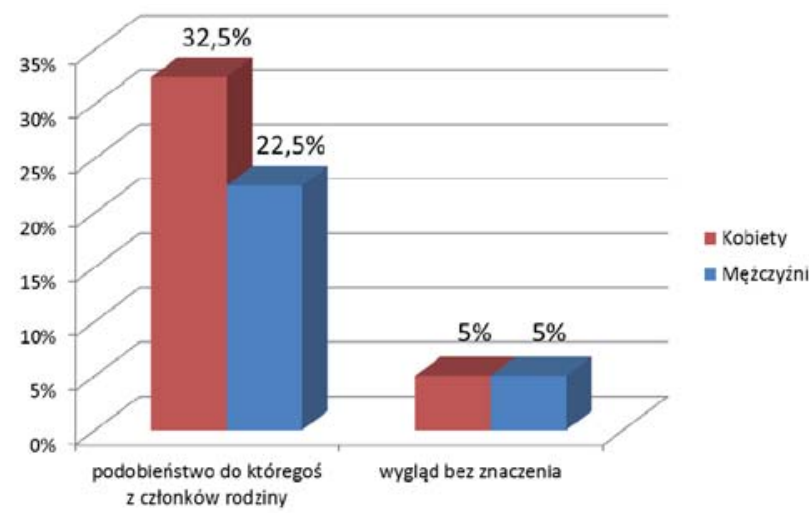

Rycina 6. Wyobrażenia rodziców na temat wyglądu dziecka w życiu prenatalnym

Kolejne dwa pytania związane były z projekcją wizualizacji dziecka. Rycinom 7 i 8 przypisana została kategoria odpowiedzi "nie wiem". Oznacza ona brak pewności badanej osoby, czy przeprowadzała wizualizację dziecka, 
ponieważ część ankietowanych za wizualizację uważała obejrzenie obrazu dziecka podczas badania USG.

Jednak, jak wynika z ryciny 7 , ponad połowa badanych kobiet (22 tj. 55\%) przyznała, że stosuje tę technikę kontaktu z dzieckiem.

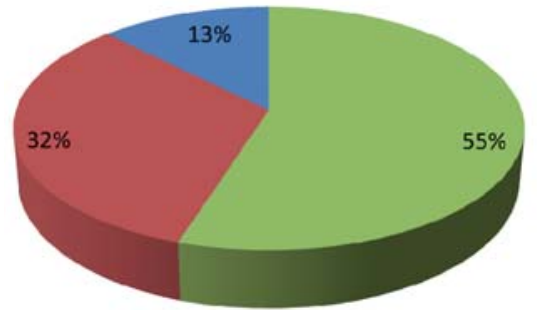

tak

nie

nie wiem

Rycina 7. Projekcja wizualizacji dziecka - wskazania kobiet

Natomiast z ryciny $\mathbf{8}$ wynika, że ojcowie rzadziej sięgali po tę formę kontaktu $z$ dzieckiem nienarodzonym. Przeprowadzanie wizualizacji zadeklarowało 13 (tj. 32,5\%) mężczyzn.

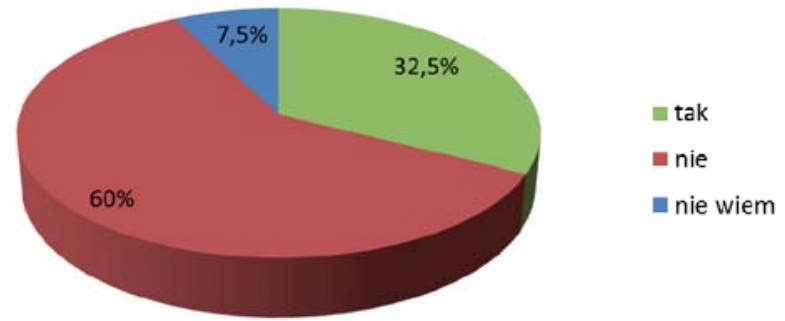

Rycina 8. Projekcja wizualizacji dziecka - wskazania mężczyzn

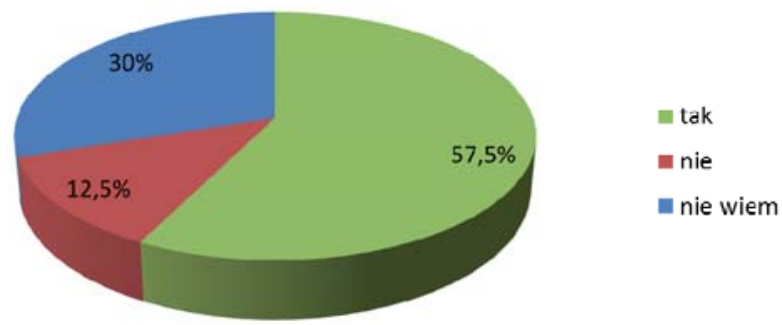

Rycina 9. Czy wizualizacja pomaga Pani w akceptacji ciąży i przyjęciu dziecka

Ostatnie pytanie kierowane do rodziców dotyczyło znaczenia wizualizacji dziecka w zaakceptowaniu ciąży i jego przyjęciu. Wśród odpowiedzi niezależnie od płci, przeważały odpowiedzi potwierdzające ten stan rzeczy, co obrazują ryciny 9 i 10.

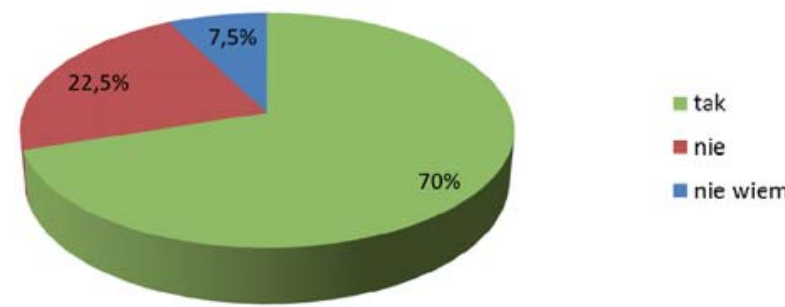

Rycina 10. Czy wizualizacja pomaga Panu w akceptacji ciąży żony i przyjęciu dziecka

\section{Omówienie wyników badań}

Wizualizacja to krok w nawiązywaniu więzi między dzieckiem a rodzicami. Wykorzystywana jest jako jedna z metod kontaktu z dzieckiem. Samo pojęcie jednak ma szersze znaczenie - „techniki relaksacji i wizualizacji umożliwiają wykorzystanie i uświadomienie sobie treści zawartych w podświadomości" [9]. Codzienne sięganie po tę technikę w połączeniu z relaksem ma korzystny wpływa na procesy fizjologiczne dla mamy i dziecka. Wizualizację należy stosować przez kilkanaście minut każdego dnia w wygodnej pozycji i atmosferze spokoju.

Pomimo że ankietowani udzielili odpowiedzi na temat wyobrażeń dotyczących wyglądu dziecka, w większości nie zinterpretowali tych treści pod pojęciem „wizualizacja”. Określenie to częściej utożsamiali z obrazem na monitorze podczas badania USG.

Natomiast wyobrażenie na temat wyglądu dziecka opisywali jako podobieństwa do kogoś z rodziny, dodatkowo przypisując inne cechy, jakie może wykazywać dziecko po urodzeniu.

Wiele wcześniejszych badań wskazuje na znaczący wpływ nawiązywania kontaktu rodziców z dzieckiem nienarodzonym poprzez dotyk obojga rodziców. Badanie przeprowadzone na brytyjskim Uniwersytecie w Dundee wykazało, że płód silniej reaguje na dotyk matki niż na jej głos. Dowiedli, że podczas głaskania brzucha matki - maluch wykonuje najwięcej ruchów. Naukowcy przekonują, że ruchy dziecka były celowe i stanowiły reakcję na bodziec pochodzący od matki. Eksperyment wykazał również, że dzieci były bardziej "ruchliwe" w trzecim trymestrze ciąży niż w drugim oraz, że dotykanie brzucha poleca się również $w$ trakcie porodu. To nie tylko uspokaja maleństwo, ale pomaga kobiecie.

Haptonomia to nauka o uczuciach, polega na nawiązaniu kontaktu z dzieckiem $w$ łonie matki i przyczynia się do wczesnego zbudowania podstaw mocnej więzi uczuciowej, szczególnie dedykowana jest mężczyznom. Poprzez dotyk brzucha kobiety ojcowie stopniowo uczą się czego potrzebuje i co lubi ich dziecko [3]. 
Należy również pamiętać, że wiele par w Polsce (choć oficjalnie tego nie przyznają) ma problem z poczęciem dziecka i w ich przypadku wiadomość o ciąży odbierana jest wyłącznie pozytywnie. Każde nawiązanie kontaktu sprzyja tworzeniu obrazu dziecka w wyobraźni kobiety i mężczyzny. Im ten obraz jest wyraźniejszy, bardziej kompletny, tym więź z dzieckiem staje się mocniejsza, a jego obecność realna, co z kolei bardziej motywuje do przygotowania się do odbycia porodu. Spostrzeżenia te znajdują potwierdzenie w wynikach i hipotezach badania ankietowego przeprowadzonego na potrzeby niniejszej pracy.

\section{Wnioski}

1. Uczestnicy szkół rodzenia będący zarówno w pierwszej i kolejnych ciążach, po pierwszym badaniu USG, akceptują ciążę i nawiązują kontakt z dzieckiem.

2. Ankietowani potwierdzili, że wyobrażenia kierowane pod adresem nienarodzonego dziecka mają pozytywny wpływ na uczucia związane z oczekiwaniem jego narodzin.

3. Większość rodziców nawiązuje kontakt emocjonalny z dzieckiem i projektuje jego wizualizację, czasami przypisując podobieństwa do któregoś z członków rodziny.

\section{Oświadczenia}

Oświadczenie dotyczące konfliktu interesów

Autorzy deklarują brak konfliktu interesów.

\section{Źródła finansowania}

Autorzy deklarują brak źródeł finansowania.
Piśmiennictwo

1. Bielewska-Bartowicz E. Psychologiczne aspekty prokreacji. Biblioteka Pracownika Socjalnego. Wydawnictwo Śląsk, Katowice 2006.

2. Drozda L. Otffinowska A. Podręcznik dla instruktorów szkół rodzenia. Fundacja Rodzic po ludzku, Warszawa 2001.

3. Dolto C. Haptonomia - emocjonalne przyjęcie dziecka przez rodziców w ciąży i w okresie poporodowym. Materiał z konferencji „dialog z dzieckiem i rodziną". Fundacja Rodzić po Ludzku, Warszawa 2001.

4. Fiałkowski W. Rodzi się człowiek. Państwowy Zakład Wydawnictw Lekarskich Warszawa 2002.

5. Kornas-Biela D. Wokół początków życia ludzkiego PAX, Warszawa 2004.

6. Kornas-Biela D. Oblicza macierzyństwa. Katolicki Uniwersytet Lubelski, Lublin 1999.

7. Kornas-Biela D. Jak powstałem. Human Life International Europa, Gdańsk 1998.

8. Leboyer F. Narodziny bez przemocy. Instytut Wydawniczy PAX, Warszawa 1996.

9. Paul-Cavallier FJ. Wizualizacja. Dom Wydawniczy Rebis, Poznań 2001.

10. Rakowiecki S. Ciąża, poród połóg. Państwowy Zakład Wydawnictw Lekarskich, Warszawa 1998.

11. Rugh R, Shettles LB. Od poczęcia do narodzin. Państwowy Zakład Wydawnictw Lekarskich 1999.

Zaakceptowano do edycji: 20.08.19 Zaakceptowano do publikacji: 26.09.19

Adres do korespondencji:

Teresa Slosorz

Wyższa Szkoła Inżynierii i Zdrowia

Wydział Nauk o Zdrowiu

ul. Bitwy Warszawskiej 1920 r. 18

02-366 Warszawa 